\title{
Seroepidemiology for MERS coronavirus using microneutralisation and pseudoparticle virus neutralisation assays reveal a high prevalence of antibody in dromedary camels in Egypt, June 2013
}

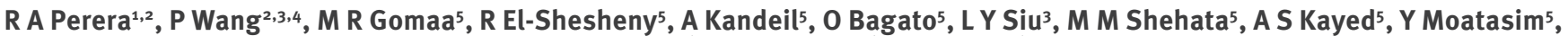

M Li³, L L Poon ${ }^{1}$, Y Guan ${ }^{1}$, R J Webby 6 , M A Ali5, J S Peiris (malik@hku.hk) ${ }^{1}$, G Kayali (ghazi.kayali@stjude.org)

1. Centre of Influenza Research, School of Public Health, The University of Hong Kong, Hong Kong, China

2. These authors contributed equally to the work and are joint first authors

3. Hong Kong University-Pasteur Research Pole, The University of Hong Kong, Hong Kong, China

4. Key Laboratory of Protein and Peptide Pharmaceuticals, Chinese Academy of Sciences - University of Tokyo Joint Laboratory of Structural Virology and Immunology, Beijing, China

5. Division of Environmental Research, National Research Centre, Giza, Egypt

6. Division of Virology, Department of Infectious Diseases, St Jude Children's Research Hospital, Memphis, United States

Citation style for this article:

Perera RA, Wang P, Gomaa MR, El-Shesheny R, Kandeil A, Bagato O, Siu LY, Shehata MM, Kayed AS, Moatasim Y, Li M, Poon LL, Guan Y, Webby RJ, Ali MA, Peiris JS, Kayali G. Seroepidemiology for MERS coronavirus using microneutralisation and pseudoparticle virus neutralisation assays reveal a high prevalence of antibody in dromedary camels in Egypt, June 2013.

Euro Surveill. 2013;18(36):pii=20574. Available online: http://www.eurosurveillance.org/ViewArticle.aspx?Articleld=20574

Article submitted on 26 August 2013 / published on 5 September 2013

We describe a novel spike pseudoparticle neutralisation assay (ppNT) for seroepidemiological studies on Middle East respiratory syndrome coronavirus (MERSCoV) and apply this assay together with conventional microneutralisation ( $M N$ ) tests to investigate 1,343 human and 625 animal sera. The sera were collected in Egypt as a region adjacent to areas where MERS has been described, and in Hong Kong, China as a control region. Sera from dromedary camels had a high prevalence of antibody reactive to MERS-CoV by MERS NT (93.6\%) and MERS ppNT (98.2\%) assay. The antibody titres ranged up to 1,280 and higher in $M N$ assays and 10,240 and higher in ppNT assays. No other investigated species had any antibody reactivity to MERS-CoV. While seropositivity does not exclude the possibility of infection with a closely related virus, our data highlight the need to attempt detection of MERS$\mathrm{CoV}$ or related coronaviruses in dromedary camels. The data show excellent correlation between the conventional MN assay and the novel ppNT assay. The newly developed ppNT assay does not require Biosafety Level 3 containment and is thus a relatively high-throughput assay, well suited for large-scale seroepidemiology studies which are needed to better understand the ecology and epidemiology of MERS-CoV.

\section{Introduction}

A novel lineage $C$ beta-coroanvirus was isolated from a patient with fatal viral pneumonia in Saudi Arabia in 2012 and termed Middle East respiratory syndrome coronavirus (MERS-CoV) [1]. As of 3 September 2013, 108 human cases have been confirmed, 50 of which were fatal [2]. Locally acquired cases have been reported from Jordan, Qatar, Saudi Arabia and the United Arab Emirates, and imported index cases, sometimes with secondary local transmission, have been reported in France, Germany, Italy, Tunisia and the United Kingdom [2-4]. Clusters of cases suggestive of limited humanto-human transmission have been reported; the largest cluster of cases to date occurred at a healthcare facility in Al-Hasa, Saudi Arabia [5]. The epidemiology of the disease so far is suggestive of multiple zoonotic transmissions from an animal reservoir leading to human infection, sometimes with secondary transmission events in humans.

Phylogenetically closely related, although not identical, viruses have been found in insectivorous bats in Africa and Europe [6,7]. More recently, a very short fragment (181 bp) of the RNA-dependent RNA polymerase gene that was genetically identical to MERS-CoV has been detected in a Taphozous perforatus bat captured in the vicinity of the residence of a human case with MERS [8]. These findings remain to be confirmed with more definitive sequence data. Even if MERS-CoV is found in bats, the possibility of an intermediate peridomestic host remains important to explore.

Since antibody responses following coronavirus infection remain detectable for many years [9], seroepidemiology of potential animal species for MERS-CoV-specific antibody is a logical approach to identify candidate species for further investigation. A recent report suggests that MERS-CoV antibody was detected in dromedary camels in the Arabian peninsula [10]. While a number of serological tests, including ELISA assays, immunoflourescence assays and immunoassays using recombinant viral proteins have been used for detecting serological responses in infected humans $[11,12]$, virus neutralisation is the most specific serological 
test and currently considered the gold-standard. However, virus neutralisation requires the handling of live virus and requires Biosafety Level 3 containment. We have therefore developed a pseudoparticle neutralisation (ppNT) assay where the spike protein of MERS$\mathrm{CoV}$ is expressed by a replication-incompetent human immunodeficiency (HIV) virus that contains a luciferase reporter gene. Similar pseudotype viruses have been used successfully in serological tests for severe acute respiratory syndrome coronavirus (SARS-CoV) and influenza viruses such as the highly pathogenic avian influenza $\mathrm{A}\left(\mathrm{H}_{5} \mathrm{~N}_{1}\right)$ virus [13]. Pseudotyped MERS-CoV has been used to study the mechanisms of virus entry, and it has been shown that cell transduction by such particles is blocked by neutralising antibodies specific for MERS-CoV [14].

The geographical distribution of MERS-CoV in its animal reservoir is not defined. Being a Middle Eastern country with an ecology and domestic livestock practices fairly similar to some countries where human MERS infections have occurred, we reasoned that Egypt would be a relevant geographical location for seroepidemiological studies. We have used both the ppNT assay and conventional microneutralisation (MN) tests to carry out seroepidemiological surveillance in humans and livestock in Egypt. Human and animal sera collected in Hong Kong were used as controls.

\section{Methods}

Sera from dromedary camels $(n=110)$, water buffaloes $(n=8)$ and cows $(n=25)$ were collected from two abattoirs, one located in Cairo and the second located in the Qalyubia governorate in the Nile Delta region. The dromedary camels were mostly imported from Sudan for slaughter and were five to seven years-old. Upon import, they were held on Egyptian farms for four to five months before transport to the abattoirs in open trucks. Sera from sheep $(n=5)$ and goats $(n=13)$ were collected from backyard animals from a village in the Nile Delta. All sera were collected in June 2013.

Human sera $(n=815)$ were collected in $2012-13$ as part of an ongoing community-based seroepidemiological study on influenza virus among healthy subjects in Cairo and the Nile Delta region. The age range of the subjects was between two and 79 years-old (median: 29 years). Fifty-eight per cent of the study subjects were female.

Sera collected in Hong Kong served as un-exposed controls. These included archived age-stratified human sera $(n=528)$ collected in Hong Kong in 2011 and 2012, with more than 50 sera from each decade of age (range: <10 to 80 years-old). Swine sera $(n=260)$ were collected from an abattoir in Hong Kong in 2011 and 2012. Sera $(n=204)$ from wild northern pintails (Anas acuta) and Eurasian widgeons (Anas penelope) were collected in December 2010 from the Mai Po wetlands nature reserve in Hong Kong.
As positive controls, we used a convalescent serum from a human patient with MERS, kindly provided by Dr C Drosten (Institute of Virology, University of Bonn Medical Centre, Bonn, Germany), and sera from two experimentally infected macaques and a non-infected control macaque kindly provided by Bart Haagmans (Erasmus University Medical Center, Rotterdam, the Netherlands).

An acute and convalescent serum from a patient with SARS was used as a further negative control. The MN antibody titre was $<10$ to SARS-CoV in the acute serum, and 160 in the convalescent serum.

The study was approved by the institutional review boards of the University of Hong Kong and St Jude Children's Research Hospital and the Ethics Committee of the National Research Centre, Egypt.

\section{Viruses and virus titration}

MERS-CoV (strain EMC) virus was obtained from Dr R Fouchier (Erasmus University Medical Center, Rotterdam, the Netherlands). SARS-CoV (strain HKU39849) was taken from the virus repository at Hong Kong University. Virus stock for MERS-CoV was prepared in Vero cell culture (ATCC CCL-81) in minimal essential medium containing $2 \%$ fetal bovine serum, 100 units $/ \mathrm{mL}$ penicillin and $100 \mu \mathrm{g} / \mathrm{mL}$ streptomycin. Virus aliquots were stored at $-80^{\circ} \mathrm{C}$. Virus was titrated in serial half- $\log _{10}$ dilutions (from $0.5 \log$ to $7 \mathrm{log}$ ) to obtain $50 \%$ tissue culture infectious dose $\left(\mathrm{TCID}_{50}\right)$ on 96-well tissue culture plates of Vero cells. The plates were observed in a phase contrast microscope for cytopathic effect (CPE) daily for three days. The endpoint of viral dilution leading to CPE in $50 \%$ of inoculated wells was estimated by using the Reed Muench method and designated as one $\mathrm{TCID}_{50}$. SARS-CoV was grown and titrated in the same manner with the exception that Vero E6 cells (ATCC CRL-1586) were used.

\section{Microneutralisation tests}

Serial two-fold dilutions of heat-inactivated sera $\left(56^{\circ} \mathrm{C}\right.$ for 30 minutes) were made, starting with a dilution of 1:10. The serum dilutions were mixed with equal volumes of 200 TCID $_{50}$ of MERS-CoV or SARS-CoV as indicated. After $1 \mathrm{~h}$ of incubation at $37{ }^{\circ} \mathrm{C}, 35 \mu \mathrm{L}$ of the virus-serum mixture was added in quadruplicate to Vero or Vero-E6 cell monolayers for MERS-CoV and SARS-CoV, respectively, in 96-well microtiter plates. After $1 \mathrm{~h}$ of adsorption, an additional $150 \mu \mathrm{L}$ of culture medium were added to each well and the plates incubated for three more days at $37{ }^{\circ} \mathrm{C}$ in $5 \% \mathrm{CO}_{2}$ in a humidified incubator. A virus back-titration was performed without immune serum to assess input virus dose. CPE was read at three days post infection. The highest serum dilution that completely protected the cells from CPE in half of the wells was taken as the neutralising antibody titre and was estimated using the Reed-Muench method. Positive and negative control sera were included to validate the assay. 
MERS-CoV spike pseudoparticle neutralisation assay

A codon-optimised spike gene was designed according to published MERS-CoV genome sequence (GenBank accession number: JX869059.1), synthesised by GeneCust (Luxembourg) and subcloned into pcDNA3.1+ vector to generate pcDNA-S. To produce HIV/MERS spike pseudoparticles, $10 \mu \mathrm{g}$ pNL Luc E R and $10 \mu \mathrm{g}$ pcDNA-S were co-transfected into $4 \times 10^{6} 293$ T cells [13]. Supernatants of transfected cells were harvested $48 \mathrm{~h}$ later and quantified for HIV p24 viral protein using a p24 ELISA Kit (Cell Biolabs, San Diego, United States).

For the ppNT assay, HIV/MERS pseudoparticles containing $5 \mathrm{ng}$ p24 were used to infect Vero E6 cells (ATCC CRL-1586) in a single well (96-well plate format; $1 \times 10^{4}$ cells/well). Infected cells were lysed in $20 \mu \mathrm{l}$ lysis buffer and $100 \mu \mathrm{l}$ of luciferase substrate at two days postinfection (Promega Corporation, Madison, United States). Luciferase activity was measured in a Microbeta luminometer (PerkinElmer, Waltham, United States).

For the ppNT, HIV/MERS pseudoparticles ( $5 \mathrm{ng}$ of p24) were pre-incubated with serially diluted sera for $30 \mathrm{~min}$ at $4{ }^{\circ} \mathrm{C}$ and then added to cells in triplicate. Residual virus replication was assayed at two days post infection, as described above. The highest serum dilution giving a $90 \%$ reduction of luciferase activity was regarded as the ppNT antibody titre.

\section{Results}

Overall, 976 human and animal sera from Egypt and 992 human and animal sera from Hong Kong were tested by MN at a screening dilution of 1:10 and 1:20 (Table 1). None of the age-stratified human sera $(n=528)$, swine sera $(n=260)$ or wild bird sera $(n=204)$ collected in Hong Kong had any neutralising activity for MERS$\mathrm{CoV}$ in the MN tests. Similarly, none of the sera from humans $(n=815)$, water buffaloes $(n=8)$, cows $(n=25)$, sheep $(n=5)$ and goats $(n=13)$ collected in Egypt were positive in the screening MN tests. In contrast, 103 of 110 sera collected in Egypt from dromedary camels neutralised MERS-CoV at the screening dilution of 1:20 or higher.

Entry of MERS pseudoparticles was shown to be inhibited by increasing concentrations of $0-20 \mathrm{mM} \mathrm{NH}_{4} \mathrm{Cl}$ (data not shown), demonstrating pH dependent entry of the MERS pseudoparticles as previously reported [14]. The MERS ppNT assay was evaluated using two sera from experimentally infected macaques, one negative control serum from an uninfected macaque, a human convalescent serum from a MERS patient and five negative human control sera from Hong Kong (Figure 1).

The MERS ppNT assay was then used to screen 115 human sera from Hong Kong and 100 randomly selected human sera from Egypt which were all serologically negative for MERS-CoV. Sixteen dromedary camel sera that were positive in the $\mathrm{MN}$ screening assay were all found to have a high neutralising activity in the ppNT assay. In addition, five of six sera that were negative in the MN assay had a weak, but detectable, activity in the ppNT test (Table 1, Table 2, Figure 2). The camel sera that were found to be positive at a screening dilution of 1:20 in the MN test had antibody titres in the MERS NT screen ranging from 40 to 1,280 and higher, and MERS pPNT titres ranging from 640 to 10,240 and higher. One of the five MERS MN-negative sera was negative in the MERS ppNT assay, while the other four had low MERS ppNT titres ranging from 40 to 160.

\section{TABLE 1}

Screening results for MERS-CoV microneutralisation and MERS-CoV spike protein pseudoparticle neutralisation, human and animal samples from Egypt and Hong Kong, 2012-2013 ( $\mathrm{n}=1,968)$

\begin{tabular}{|c|c|c|c|c|c|}
\hline \multirow{2}{*}{ Sera } & \multirow{2}{*}{ Source of sera } & \multicolumn{2}{|c|}{ MERS-CoV micro-neutralisation titre $\geq 1: 20$} & \multicolumn{2}{|c|}{ MERS-CoV spike pseudotype antibody titre $\geq 1: 20$} \\
\hline & & Total tested & $\%$ Positive (n) & Total tested & $\%$ Positive (n) \\
\hline Human $^{a}$ & \multirow{6}{*}{ Egypt } & 815 & o $(0 / 815)$ & 100 & $\mathrm{o}(\mathrm{o} / 100)$ \\
\hline Goat $^{\mathrm{b}}$ & & 13 & $\mathrm{o}(\mathrm{o} / 13)$ & ND & ND \\
\hline Sheep ${ }^{b}$ & & 5 & $\mathrm{o}(0 / 5)$ & ND & ND \\
\hline Water buffalo ${ }^{b}$ & & 8 & $\mathrm{o}(\mathrm{o} / 8)$ & ND & ND \\
\hline Cow $^{b}$ & & 25 & $\mathrm{O}(0 / 25)$ & ND & ND \\
\hline Camel $^{\mathrm{b}}$ & & 110 & $93.6(103 / 110)$ & 110 & $98.2(108 / 110)$ \\
\hline Human & \multirow{3}{*}{ Hong Kong } & 528 & $0(0 / 528)$ & 115 & o (o/115) \\
\hline Swine & & 260 & $0(0 / 260)$ & ND & ND \\
\hline Wild bird & & 204 & $0(0 / 204)$ & ND & ND \\
\hline
\end{tabular}

MERS-CoV: Middle East respiratory syndrome coronavirus; ND: not done.

a Collected in 2012-13.

${ }^{b}$ Collected in June 2013.

Details of sera collected in Hong Kong as given in Methods. 
The correlation of the MERS MN and MERS ppNT titres are shown in Figure 3 (Pearson's correlation coefficient: $R=0.88$ ). The MERS ppNT test appears to be more sensitive than the MERS MN test, and thus some of the apparently MN-negative camel sera give low titre-positive results in the MERS ppNT assay. However, none of the human sera from Egypt $(n=100)$ or Hong Kong $(n=115)$ had any detectable antibody in the MERS ppNT test. None of the camel sera with high antibody titres to MERS-CoV had any cross-neutralising activity to SARS-CoV (Table 2).

\section{Discussion}

Of 1,968 human and animal sera tested by MERS-CoV MN and 325 human and animal sera tested by MERSCoV ppNT assays, only sera from dromedary camels had any neutralising antibody activity to the MERSCoV. Of the 110 camel sera, $93.6 \%$ were seropositive by MERS-CoV MN test and $98.2 \%$ were seropositive by MERS-CoV ppNT test. The antibody titres were very high in MN as well as ppNT, suggesting that the virus infecting these camels was MERS-CoV virus itself or a very closely related virus.

It is known that dromedary camels host bovine coronaviruses (BCoV) which are lineage $A$ beta-coronaviruses. However cross-neutralisation between MERS-CoV (lineage $C$ beta-coronavirus) and BCoV was excluded by Reusken and colleagues in their study of sera from dromedary camels [10]. Furthermore, BCoV is antigenically closely related to the human coronavirus $\mathrm{OC}_{43}$. Human beta-coronavirus lineage A viruses $0 C_{43}$ and

\section{FIGURE 1}

MERS-CoV spike protein pseudoparticle neutralisation, human and animal samples from Egypt and Hong Kong, 2012-13 $(n=9)$

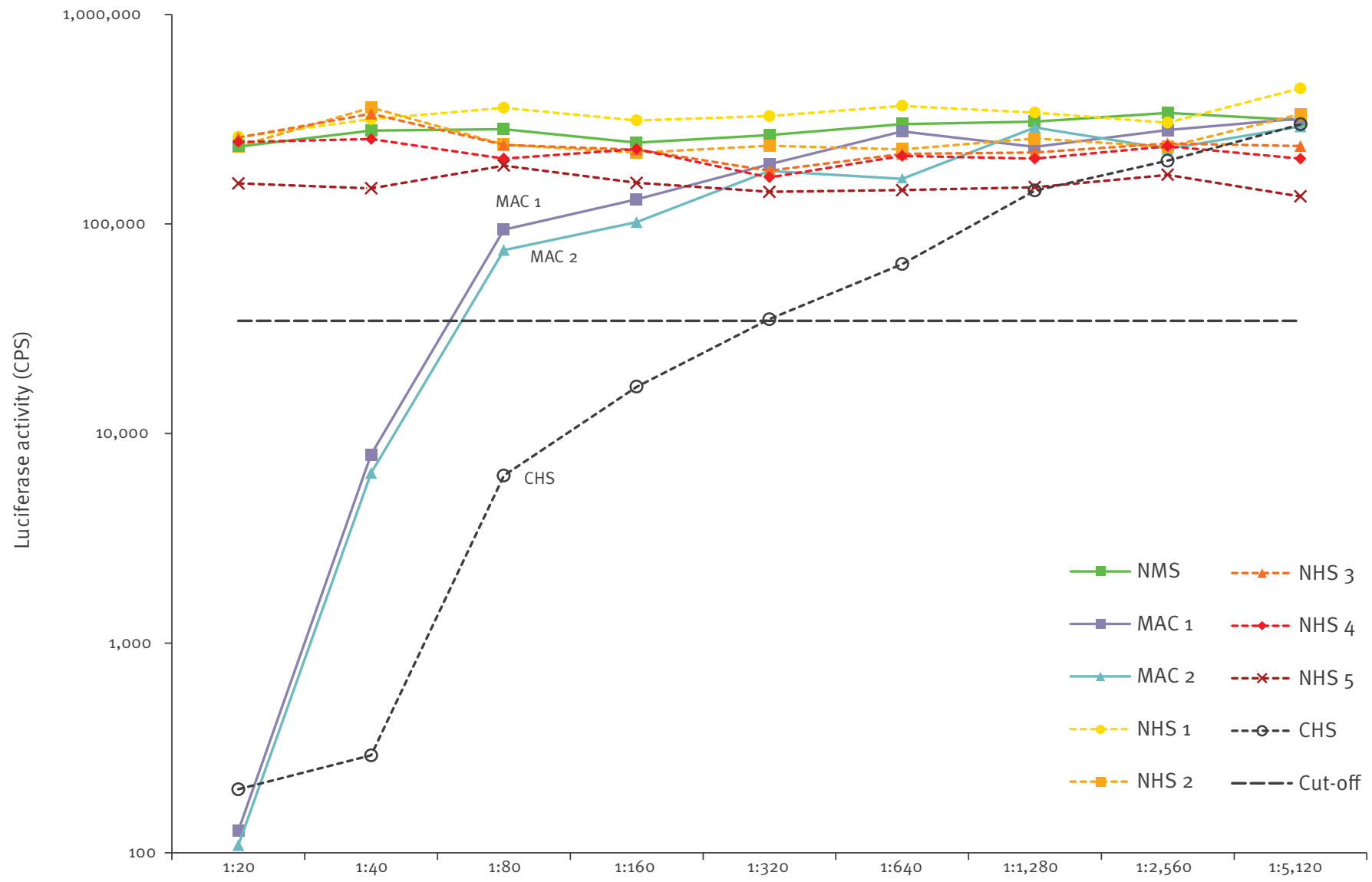

Serum dilution

CPS: counts per second; MERS-CoV: Middle East respiratory syndrome coronavirus;

As positive controls, we used a convalescent human serum (CHS) from a patient with MERS, kindly provided by Dr C Drosten (Institute of Virology, University of Bonn Medical Centre, Bonn, Germany) and sera from two experimentally infected macaques (MAC 1 , MAC 2 ), kindly provided by Bart Haagmans (Erasmus University Medical Center, Rotterdam, the Netherlands). As negative controls we used serum from a non-infected control macaque (NMS) and five human sera (NHS 1-5) from Hong Kong. The horizontal dotted line represents the 90\% reduction in luciferase activity which represents the cut-off for positivity in the assay. Each batch of assays had the cut-off determined with reference to a serum-free negative control, and the data represented here are a compilation of two experiments. Thus the cut-off line is a representative indication based on an average of cut-offs used in seperate experiments. 
$\mathrm{HKU}_{1}$, and alpha-coronaviruses (229E and NL63) are ubiquitous respiratory viruses infecting humans and the panel of human sera of different ages tested can be expected to have varying levels of antibody to these viruses. The lack of any MERS-neutralising activity in the human sera we studied also indicates that the MN and ppNT assays are specific for MERS-CoV. The lack of cross-reactivity with convalescent serum from patients with SARS provides additional evidence of the lack of cross-reactivity in the MERS-CoV serology assays. Furthermore, it is notable that the camel sera with high antibody titres to MERS-CoV did not crossreact with SARS-CoV, a beta-coronavirus of lineage $B$. Taken together these data indicate that a MERS-CoV or a highly related virus is endemic in dromedary camels imported for slaughter in Egypt. These findings provide independent confirmation of the results recently reported by Reusken et al. who found very high antibody titres to MERS-CoV in dromedary camels [10].
The dromedary camels sampled in our study were those brought to abattoirs for slaughter in Cairo and in the Qalyubia governorate in the Nile Delta region. These animals were sourced from other East African countries such as Sudan and held in Egypt for some time prior to slaughter. Thus it is unclear where the animals originally acquired the infection. Considering the similar data from dromedary camels in Oman and the Canary Islands [10], it is likely that this coronavirus is widespread in North and East Africa and the Arabian peninsula.

There is substantial movement of people between Egypt and Saudi Arabia and other states on the Arabian peninsula, and thus it is possible that people may get infected, either as part of their travel to endemic areas or through zoonotic transmission within the country. There is also much movement of livestock across these Middle Eastern countries. The lack of antibody to MERS-CoV in sera of people resident in Egypt indicates

\section{FIGURE 2}

MERS-CoV spike protein pseudoparticle neutralisation on selected sera from dromedary camels, Egypt, June, 2013 (n=21)
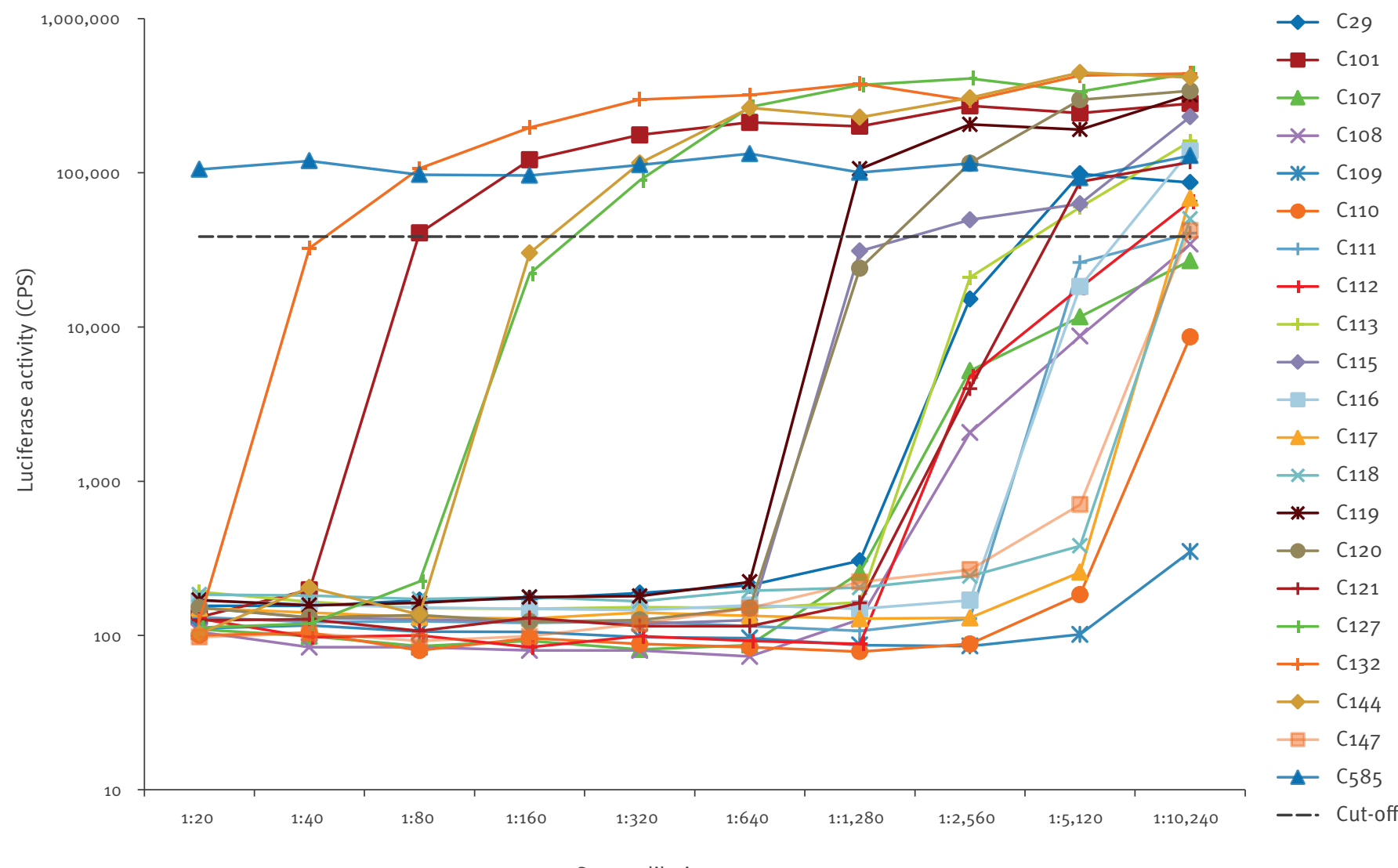

Serum dilution

CPS: counts per second; MERS-CoV: Middle East respiratory syndrome coronavirus; MN: microneutralisation; ppNT: pseudoparticle neutralisation.

Sixteen sera found to be positive and five sera found to be negative in the MERS-CoV MN screening assay were titrated in the MERS-CoV ppNT assay. The sera used are shown in Table 2 . The horizontal dotted line represents the $90 \%$ reduction in luciferase activity which represents the cut-off for positivity in the assay. Each batch of assays had the cut-off determined with reference to a serum-free negative control and the data represented here are a compilation of two experiments. Thus the cut-off line is a representative indication based on an average of cut-offs used in seperate experiments. 
that this infection is not common in Egypt, either as an infection acquired through travel or as an occasional zoonotic infection.

The MERS-CoV ppNT assay described here is a safe and specific assay for large scale seroepidemiological studies in a range of animal species, and such studies are urgently needed in regions where MERS-CoV cases have been detected as well as other regions. The HIV backbone used for pseudoparticle production is not replication-competent and the MERS-CoV pseudoparticles can therefore be produced and used in Biosafety Level 2 containment; in contrast, MN assays involve handling of the live MERS-CoV and require Biosafety Level 3 containment which is not always available in affected regions. Unlike immunoassays, there is no requirement for finding and optimising an enzymelabelled anti-Ig conjugate for each species to be investigated. Furthermore, the MERS-CoV ppNT assay appears around 10 times more sensitive than the conventional MN assay (Figure 3, Table 2). The MN assay

\section{TABLE 2}

Antibody titres of selected sera from dromedary camels tested by microneutralisation for MERS-CoV and SARS-CoV and by MERS spike protein pseudoparticle neutralisation, Egypt, June, 2013 ( $\mathrm{n}=21)$

\begin{tabular}{|c|c|c|c|}
\hline \multirow[b]{2}{*}{ Camel sera } & \multicolumn{3}{|c|}{ Antibody titres } \\
\hline & $\begin{array}{c}\text { MERS-CoV MN } \\
\text { test }\end{array}$ & $\begin{array}{c}\text { SARS-CoV MN } \\
\text { test }\end{array}$ & $\begin{array}{c}\text { MERS-CoV } \\
\text { ppNT test }\end{array}$ \\
\hline $\mathrm{C}_{101}$ & «10 Negative & «10 Negative & 40 \\
\hline $\mathrm{C}_{127}$ & «10 Negative & «10 Negative & 160 \\
\hline $\mathrm{C}_{132}$ & «10 Negative & «10 Negative & 40 \\
\hline $\mathrm{C}_{144}$ & «10 Negative & «10 Negative & 160 \\
\hline$C_{585}$ & «10 Negative & «10 Negative & <20 Negative \\
\hline C29 & 320 & «10 Negative & 2,560 \\
\hline $\mathrm{C}_{107}$ & 160 & «10 Negative & 5,120 \\
\hline $\mathrm{C}_{108}$ & 160 & «10 Negative & 5,120 \\
\hline $\mathrm{C}_{109}$ & 640 & «10 Negative & $\geq 10,240$ \\
\hline $\mathrm{C}_{110}$ & $\geq 1,280$ & «10 Negative & $\geq 10,240$ \\
\hline $\mathrm{C}_{111}$ & 320 & «10 Negative & 5,120 \\
\hline $\mathrm{C}_{112}$ & 320 & «10 Negative & 5,120 \\
\hline $\mathrm{C}_{113}$ & 320 & «10 Negative & 2,560 \\
\hline $\mathrm{C}_{115}$ & 160 & «10 Negative & 1,280 \\
\hline$C_{116}$ & 320 & «10 Negative & 5,120 \\
\hline $\mathrm{C}_{117}$ & 640 & «10 Negative & 5,120 \\
\hline $\mathrm{C}_{118}$ & 640 & «10 Negative & 5,120 \\
\hline$C_{119}$ & 80 & «10 Negative & 640 \\
\hline$C_{120}$ & 40 & «10 Negative & 1,280 \\
\hline$C_{121}$ & 160 & «10 Negative & 2,560 \\
\hline $\mathrm{C}_{147}$ & $\geq 1,280$ & «10 Negative & $\geq 10,240$ \\
\hline
\end{tabular}

MERS-CoV: Middle East respiratory syndrome coronavirus; MN: microneutralisation; ppNT: pseudoparticle neutralisation; SARSCoV: severe acute respiratory syndrome coronavirus. is a neutralisation assay based on $\mathrm{TCID}_{50}$ rather than a plaque reduction assay, which perhaps makes it less sensitive than a plaque neutralisation assay. In any event, experience with influenza virus serology using pseudoparticle assays has shown that they are more sensitive than conventional MN assays for detecting neutralising antibodies. Thus MERS-CoV ppNT can be used as a screening assay, and positive sera can be retested for confirmation in a MERS MN tests.

Serological data does not provide proof that the virus infecting dromedary camels is the MERS CoV, and infection by a closely related coronavirus or a chimeric virus with a MERS-CoV-like spike protein cannot be ruled out until the dromedary camel virus is detected and genetically sequenced. However, it provides a strong impetus to attempt to seek the virus in specimens from these animals and to identify the MERSrelated virus that appears to be infecting them. These serological studies also need to be extended to other domestic animals species to define the circulation of MERS-CoV or related viruses in animals in close contact with humans. Such studies should also include humans exposed to dromedary camels. It is important to note that waning antibody levels may result in falsenegative serology results, and this is particularly relevant in mild or asymptomatic episodes of infection where the peak antibody titre may be lower and drop more quickly.

\section{FIGURE 3}

Correlation of MERS-CoV antibody titres determined by MERS-CoV microneutralisation and MERS-CoV spike protein pseudoparticle neutralisation in selected sera from dromedary camels, Egypt, June, 2013 ( $n=21)$

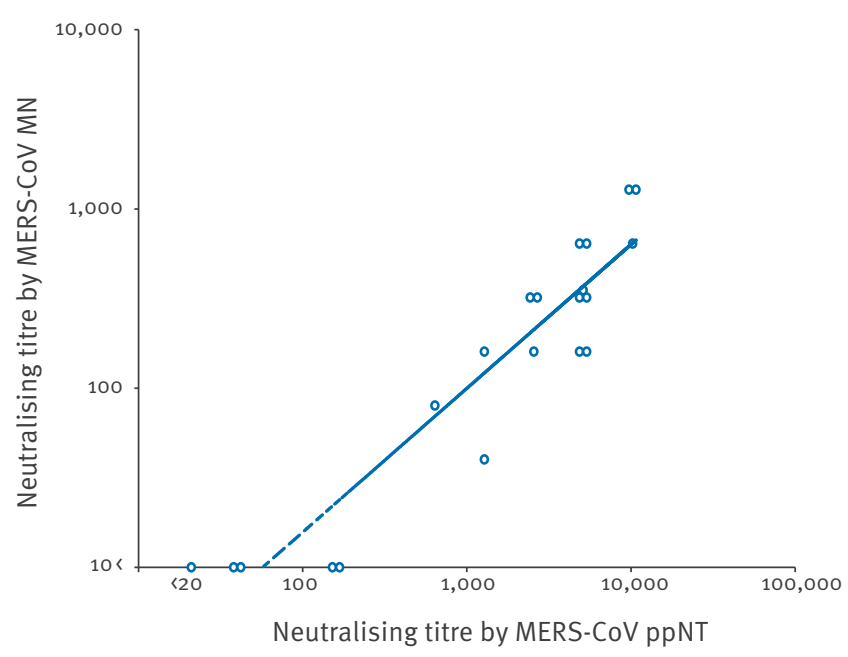

MERS-CoV: Middle East respiratory syndrome coronavirus; MN: microneutralisation; ppNT: pseudoparticle neutralisation.

The data used as those shown in Table 2. In the event of overlapping dots, their MN titre (X axis) was increased or decreased by $0.05 \%$ to slightly offset the overlap for ease of observation. The limit of detection in the MN and ppNT assays were titres of 10 and 20 respectively; and thus these values on the $\mathrm{Y}$ and $\mathrm{X}$ axis correspond to $<10$ and $<20$, respectively. 
If the detection of MERS-CoV in insectivorous bats is confirmed [8] and if indeed the coronavirus we and others demonstrated to be common in dromedary camels is confirmed to be MERS-CoV, we will have a scenario of a virus reservoir in bats with a peridomestic animal such as the camel as intermediate host, which may in fact be the immediate source of human infection. It is notable that a number of index cases with MERS-CoV had a history of exposure to camels, although this is by no means universally the case. Given that the MERSlike coronavirus in camels appears to be ubiquitous, it remains to be explained why MERS in humans appears relatively rare. Coronaviruses are well known to mutate to markedly change virulence or host range. Examples are the emergence of the less pathogenic porcine respiratory coronavirus from virulent transmissible gastroenteritis virus of pigs, or virulent feline infectious peritonitis viruses emerging from low pathogenic feline coronaviruses [15]. Furthermore, the SARS-like virus detected in civets and other small mammals in live animal markets in southern China in 2002-03 initially appeared to infect humans, who appear to have seroconverted, but with minimal disease and onward transmission [16], while a few amino acid changes in the SARS-CoV spike protein allowed that virus to acquire efficient transmissibility and virulence in humans [17]. Thus, previous experience with animal and human coronaviruses highlights the public health urgency of investigations of MERS-CoV and MERS-CoV-like viruses in domestic and wild animals.

\section{Acknowledgements}

We thank Dr CYH Leung for providing wild bird sera from Hong Kong. This study was supported in part by research contract from the National Institute of Allergy and Infectious Diseases (NIAID) contract HHSN266200700005C and a grant from the European Community Seventh Framework Programme (FP7/2007-2013) under project European management Platform for Emerging and Re-emerging Disease entities (Grant agreement No. 223498) (EMPERIE).

\section{Conflict of interest}

None declared.

\section{Authors' contributions}

Pei-gang Wang developed the MERS-CoV pseudotype assay and carried out the tests. Ranawaka AMP Perera developed the MERS-CoV microneutralisation test and carried out the tests in BSL3 containment. Leo LLM Poon and Yi Guan provided advice on laboratory methods. Lewis YL Siu and Mingyuan Li carried out the MERS-CoV pseudoparticle assays. Mokhtar R. Gomaa, Rabeh El-Shesheny, Ahmed Kandeil, Ola Bagato, Mahmoud M. Shehata, Ahmed S. Kayed and Yassmin Moatasim collected human and animal sera in Egypt. Richard J. Webby and Mohamed A. Ali provided advice on field study design. Joseph SM Peiris and Ghazi Kayali designed and coordinated the study and wrote the manuscript. All authors reviewed and commented on the manuscript.
References

1. Zaki AM, van Boheemen S, Bestebroer TM, Osterhaus AD, Fouchier RA. Isolation of a novel coronavirus from a man with pneumonia in Saudi Arabia. N Engl J Med. 2012;367(19):181420. http://dx.doi.org/10.1056/NEJMoa1211721. PMid:23075143.

2. World Healh Organization (WHO). Middle East respiratory syndrome coronavirus (MERS-CoV) - update. Geneva: WHO; 29 Aug 2013. Available from: http://www.who.int/csr/ don/2013 08 29/en/index.html

3. World Healh Organization (WHO). Middle East respiratory syndrome coronavirus (MERS-CoV) summary and literature update - as of 9 July 2013. Geneva: WHO. [Accessed 20 Aug 2013]. Available from: http://www.who.int/csr/disease/ coronavirus_infections/update_20130709/en/index.html

4. Bermingham A, Chand MA, Brown CS, Aarons E, Tong C, Langrish C, et al. Severe respiratory illness caused by a novel coronavirus, in a patient transferred to the United Kingdom from the Middle East, September 2012. Euro Surveill. 2012;17(40): pii=20290. http://www.eurosurveillance.org/ ViewArticle. aspx?Articleld $=20290$

5. Assiri A, McGeer A, Perl TM, Price CS, Al Rabeeah AA, Cummings DA, et al. Hospital outbreak of Middle East respiratory syndrome coronavirus. N Engl J Med. 2013;369(5):407-16. http://dx.doi.org/10.1056/ NEJMoa1306742. PMid:23782161.

6. Annan A, Baldwin HJ, Corman VM, Klose SM, Owusu M, Nkrumah EE, et al. Human betacoronavirus 2C EMC/2012related viruses in bats, Ghana and Europe. Emerg Infect Dis. 2013:19(3):456-9. http://dx.doi.org/10.3201/eid1903.121503. PMid:23622767. PMCid:PMC3647674.

7. Ithete NL, Stoffberg S, Corman VM, Cottontail VM, Richards LR, Schoeman MC, et al. Close relative of human Middle East respiratory syndrome coronavirus in bat, South Africa. Emerg Infect Dis. 2013. EPub ahead of print. DOI: 10.3201/ eid1910.130946. http://dx.doi.org/10.3201/eid1910.130946

8. Memish ZA, Mishra N, Olival KJ, Fagbo SF, Kapoor V, Epstein $\mathrm{JH}$, et al. Middle East respiratory syndrome coronavirus in bats, Saudi Arabia. Emerg Infect Dis. 2013. EPub ahead of print. DOI: 10.3201/eid1911.131172. http://dx.doi.org/10.3201/ eid1911.131172

9. Cao WC, Liu W, Zhang PH, Zhang F, Richardus JH. Disappearance of antibodies to SARS-associated coronavirus after recovery. N Engl J Med. 2007;357(11):1162-3. http://dx.doi. org/10.1056/NEJMC070348. PMid:17855683.

10. Reusken CB, Haagmans BL, Müller MA, Gutierrez C, Godeke GJ, Meyer B, et al. Middle East respiratory syndrome coronavirus neutralising serum antibodies in dromedary camels: a comparative serological study. Lancet Infect Dis. 2013; pii: S1473-3099(13)70164-6. DOI: 10.1016/S1473-3099(13)70164-6. http://dx.doi.org/10.1016/S1473-3099(13)70164-6

11. Corman VM, Muller MA, Costabel U, Timm J, Binger T, Meyer B, et al. Assays for laboratory confirmation of novel human coronavirus (hCoV-EMC) infections. Euro Surveill. 2012;17(49): pii=20334. Available from: http://www. eurosurveillance.org/ViewArticle.aspx?Articleld =20334

12. Reusken C, Mou H, Godeke GJ, van der Hoek L, Meyer B, Muller $M A$, et al. Specific serology for emerging human coronaviruses by protein microarray. Euro Surveill. 2013;18(14):20441. Available from: http://www.eurosurveillance.org/ViewArticle. aspx?Articleld =20441.PMid:23594517

13. Garcia JM, Lagarde N, Ma ES, de Jong MD, Peiris JS Optimization and evaluation of an influenza $\mathrm{A}\left(\mathrm{H}_{5}\right)$ pseudotyped lentiviral particle-based serological assay. j Clin Virol. 2010;47(1):29-33. http://dx.doi.org/10.1016/j. jcv.2009.10.009. PMid:19897409.

14. Gierer S, Bertram S, Kaup F, Wrensch F, Heurich A, Krämer-Kühl $A$, et al. The spike protein of the emerging betacoronavirus EMC uses a novel coronavirus receptor for entry, can be activated by TMPRSS 2 , and is targeted by neutralizing antibodies. J Virol. 2013;87(10):5502-11. http://dx.doi. org/10.1128/JVI.00128-13. PMid:23468491.

15. Saif LJ. Animal coronaviruses: what can they teach us about the severe acute respiratory syndrome? Rev Sci Tech. 2004;23(2):643-60. PMid:15702725

16. Guan Y, Zheng BJ, He YQ, Liu XL, Zhuang ZX, Cheung CL, et al. Isolation and characterization of viruses related to the SARS coronavirus from animals in southern China. Science. 2003;302(5643):276-8. http://dx.doi.org/10.1126/ science.1087139. PMid:12958366.

17. Li F. Structural analysis of major species barriers between humans and palm civets for severe acute respiratory syndrome coronavirus infections. J Virol. 2008;82(14):698491. http://dx.doi.org/10.1128/JVI.00442-08. PMid:18448527. PMCid:PMC2446986. 